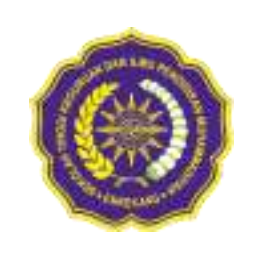

\title{
PERBANDINGAN MOTIVASI BELAJAR DAN HASIL BELAJAR BIOLOGI MATERI SISTEM INDERA MELALUI STRATEGI PEMBELAJARAN TANDUR DAN STRATEGI PEMBELAJARAN EKSPOSITORI PADA SISWA KELAS XI IPA SMA NEGERI 8 MAKASSAR
}

\section{DIAN FIRDIANI}

\author{
STKIP Muhammadiyah Enrekang, Indonesia \\ E-mail:dianfirdianil@gmail.com
}

\begin{abstract}
The comparation of learning motivation and biological students' learning achievement in sense system through TANDUR teaching strategy and expository teaching strategy at grade XI Exact Senior High School 8 Makassar. This research aims at finding out the potency of the integration strategy of PBL with cooperative learning of Jigsaw in improving the critical thinking skills of the students. This research belongs to quasi-experimental with pretest-posttest nonequivalent control group design factorial $2 \times 2$. The research population is the new student of four study programs: Biology, Biology Education, Chemistry, and Chemistry Education in the faculty of Math and Science UNM in academic years 2017/2018. The research samples selected in two classes, Chemistry Education $(\mathrm{N}=36)$ as the experimental class, and Biology class $(\mathrm{N}=30)$ as a control class (using conventional strategy). Critical thinking skills consist of interpretation, analysis, evaluation, inference, explanation, and self-regulation. The research data were collected by giving test before and after treatment then analyzed using descriptive and inferential statistics. The research result shows that the strategy of learning has an influence on the critical thinking skills of the students so that the integration strategy of PBL+Jigsaw has more potency to improve critical thinking skills of the students rather than conventional one.
\end{abstract}

\begin{abstract}
Abstrak: Perbandingan Motivasi Belajar dan Hasil Belajar Biologi Materi Sistem Indera Melalui Strategi Pembelajaran Tandur dan Strategi Pembelajaran Ekspositori pada Siswa Kelas XI IPA SMA Negeri 8 Makassar. Penelitian ini bertujuan untuk 1)Mengetahui motivasi belajar melalui strategi pembelajaran TANDUR dan strategi pembelajaran ekspositori siswa kelas XI IPA SMA Negeri 8 Makassar; 2) Mengetahui hasil belajar melalui strategi pembelajaran TANDUR dan strategi pembelajaran ekspositori siswa kelas XI IPA SMA Negeri 8 Makassar; 3) Mengetahui perbedaan tingkat motivasi belajar melalui strategi pembelajaran TANDUR dan strategi pembelajaran ekspositori siswa kelas XI IPA SMA Negeri 8 Makassar. Penelitian ini merupakan penelitian eksperimen semu (Quasy Experiment). Sampel dalam penelitian ini adalah siswa kelas XI IPA4 dan XI IPA5 SMA Negeri 8 Makassar semester ganjil tahun ajaran 2017/2018 yang berjumlah 71 orang, diperoleh dengan menggunakan Simple Random Sampling, kelas XI IPA5 diajar melalui strategi pembelajaran TANDUR dengan jumlah siswa sebanyak 38 orang, sedangkan kelas XI IPA4 diajar melalui strategi pembelajaran ekspositori dengan jumlah siswa sebanyak 33 orang. Data yang telah diperoleh selanjutnya dianalisis dengan menggunakan teknik analisis deskriptif dan inferensial. Hasil penelitian menunjukkan motivasi belajar kelas yang diajar melalui strategi TANDUR untuk kategori sangat rendah $7.89 \%$, rendah $7.89 \%$, sedang $57.89 \%$, tinggi $26.33 \%$, sedangkan motivasi belajar kelas yang diajar melalui strategi ekspositori untuk kategori rendah $51.53 \%$, sedang $18.18 \%$, tingg $18.18 \%$, sangat tinggi $12.12 \%$. Hasil belajar biologi materi sistem indera yang diajar melalui strategi TANDUR untuk kategori amat baik $18.42 \%$, baik $81.58 \%$, sedangkan hasil belajar kelas yang diajar melalui startegi ekspositori unutk kategori amat baik $15.15 \%$, baik $84.85 \%$. Berdasarkan hasil tersebut dapat disimpulkan bahwa ada perbedaan motivasi belajar melalui strategi pembelajaran TANDUR dan strategi pembelajaran ekspositori siswa kelas XI IPA SMA Negeri 8 Makassar, dimana motivasi belajar siswa melalui strategi TANDUR lebih tinggi dibanding dengan strategi ekspositori dan ada perbedaan hasil belajar biologi materi sistem indera melalui strategi pembelajaran TANDUR dan strategi pembelajaran ekspositori siswa kelas XI IPA SMA Negeri 8 Makassar, dimana hasil belajar dengan menerapkan strategi TANDUR lebih tinggi dibanding dengan penerapan strategi ekspositori.
\end{abstract}

Kata kunci: TANDUR, Ekspositori, Motivasi Belajar, Hasil Belajar. 


\section{A. PENDAHULUAN}

Dalam UU Sisdiknas No. 20 Tahun 2003 pasa 4 ayat 1 menyebutkan bahwa salah satu tujuan pendidikan adalah membentuk manusia yang bertanggung jawab terhadap kesejahteraan masyarakat dan tanah air. Indonesia terus menerus melakukan berbagai upaya dalam peningkatan kualitas pendidikan. Upaya tersebut antara lain, perubahan kurikulum, perbaikan fasilitas, peningkatan mutu SDM, dan sebagainya (Webe, 2010:17).

Keberhasilan peningkatan kualitas pendidikan tidak luput dari proses belajar mengajar di sekolah yang melibatkan guru dan siswa. Dalam proses belajar mengajar, keduanya akan saling berinteraksi untuk mencapai tujuan pembelajaran. Salah satu faktor yang mempengaruhi keberhasilan pencapaian tujuan pembelajaran adalah kemampuan guru dalam melaksanakan pembelajaran. Pembelajaran yang dilaksanakan oleh guru menyenangkan dan dapat menciptakan suasana yang kondusif maka siswa juga dapat menerima pelajaran dengan baik dan lengkap, sebaliknya jika guru tidak mampu melaksanakan pembelajaran yang menyenangkan siswa, maka siswa akan merasa tidak nyaman selama proses belajar mengajar berlangsung. Keadaan seperti ini sangatlah berpengaruh terhadap informasi yang diterima oleh siswa. Kenyamanan dalam belajar merupakan faktor penunjang banyak sedikitnya informasi yang diterima selama proses pembelajaran berlangsung. Kenyamanan yang dirasakan oleh siswa akan membuat mereka lebih berani mengambil resiko menghadapi kesulitan dan belajar lebih banyak lagi (DePorter et al., 2002: 47).

SMA Negeri 8 Makassar merupakan salah satu lembaga pendidikan yang menjunjung keberhasilan pembelajaran untuk menghasilkan siswa yang mampu berperan dalam persaingan global. Telah banyak dilakukan usaha untuk mencapai tujuan tersebut dengan harapan dapat menciptakan manajemen pembelajaran dengan baik untuk menjadi lembaga pendidikan yang berkualitas. Kenyataannya usaha yang dilakukan pihak sekolah masih belum membuahkan hasil yang maksimal. Hal tersebut terjadi karena guru masih menggunakan pembelajaran yang monoton dan kurang mampu menciptakan suasana yang kondusif selama proses pembelajaran berlangsung, sehingga siswa kurang berminat terhadap pelajaran yang diberikan oleh guru.

Dalam upaya menciptakan suasana belajar mengajar yang kondusif, guru perlu memperhatikan prinsip-prinsip mengajar diantaranya menggunakan strategi pembelajaran. Penggunaan strategi pembelajaran pada hakikatnya memberi pengaruh terhadap pengoptimalan kegiatan belajar siswa. Dengan pembelajaran yang monoton membuat siswa jenuh untuk belajar. Kejenuhan inilah yang mengakibatkan pembelajaran menjadi kurang efektif. Caroll dan rekan-rekannya mengemukakan bahwa faktor dominan yang mempengaruhi taraf penguasaan belajar adalah kualitas pengajaran dan taraf kemampuan siswa untuk memahami pengajaran itu (Makmun 2005: 235). Terutama untuk mata pelajaran yang dianggap rumit bagi siswa seperti mata pelajaran biologi yang mengutamakan pemahan konsep dari setiap materi. Pemahaman siswa akan materi yang diberikan juga dipengaruhi oleh motivasi belajar siswa, jika guru terus menggunakan pembelajaran yang monoton maka motivasi siswa juga kurang sehingga berpengaruh terhadap hasil belajar siswa.

Siswa yang memiliki motivasi tinggi memiliki keinginan untuk selalu melakukan kegiatan yang mampu meningkatkan pencapaian hasil belajar. Pernyataan ini sesuai dengan pendapat Hamalik (2004) yang menjelaskan bahwa motivasi menyebabkan perubahan energi dalam diri seseorang sehingga akan mempengaruhi kondisi psikologis dan emosinya sehingga menghasilkan tindakan untuk mencapai tujuan. Oleh sebab itu motivasi merupakan faktor yang diketahui sangat berhubungan dengan hasil belajar. Pendapat tersebut dikuatkan oleh beberapa peneliti terdahulu seperti yang dilakukan oleh Tella (2007) yang mendapatkan hasil bahwa motivasi memiliki hubungan positif dengan hasil belajar yang dicapai siswa dimana siswa dengan motivasi yang tinggi maka hasil belajarnya juga tinggi.

Pada mata pelajaran biologi khususnya materi sistem indera, kemampuan yang harus dimiliki oleh siswa setelah mempelajari materi sistem indera adalah menjelaskan keterkaitan struktur, fungsi dan proses serta kelainan atau penyakit yang disebabkan oleh gangguan sistem indera. Materi yang harus dikuasai tersebut mengandung konsep yang menggunakan bahasa ilmiah dan pemahaman proses sehingga dianggap 
sebagai materi yang sulit bagi siswa. Pernyataan tersebut di dukung oleh penelitian yang dilakukan oleh Tekkaya et al. (2001) mengenai konsep biologi yang dianggap sulit oleh siswa sekolah menengah atas.

Proses pembelajaran biologi di sekolah ini masih menggunakan pembelajaran yang monoton yang berorientasi pada transfer pengetahuan saja. Padahal seharusnya siswa yang punya karakter beragam memerlukan perlakuan khusus dari guru agar mampu mengambil makna dari setiap informasi yang diberikan. Untuk itu guru harus mampu melibatkan mereka dalam proses belajar mengajar.

Berdasarkan permasalahan di atas, maka diperlukan tindakan sebagai solusi dari permasalah tersebut. Salah satunya adalah penerapan strategi pembelajaran yang membuat kegiatan belajar siswa menjadi lebih menyenangkan. Strategi pembelajaran inilah yang berperan untuk menciptakan proses dalam pembelajaran. Dari beberapa strategi pembelajaran yang ada, strategi pembelajaran TANDUR dan strategi pembelajaran ekspositori diharapkan mampu membantu siswa untuk mencapai tujuan pembelajaran.

Strategi TANDUR merupakan bagian dari pembelajaran yang inovatif yaitu Quantum Teaching. Quantum Teaching merupakan bentuk inovasi penggubahan bermacam-macam interaksi yang ada dalam dan sekitar momen belajar (Udin, 2008). Strategi pembelajaran TANDUR telah diterapkan pada perusahaan pendidikan internasional yaitu SuperCamp. Dalam program ini, siswa memperoleh kiat-kiat yang membantu mereka dalam mencatat, menghafal, menulis, membaca cepat, berkreativitas, berkomunikasi dan membina hubungan serta kiat-kiat yang meningkatkan kemampuan mereka menguasai segala hal dalam kehidupan. Hasilnya menunjukkan bahwa siswa yang mengikuti SuperCamp mendapatkan nilai yang lebih baik, lebih banyak berpartisipasi, dan merasa lebih bangga akan diri mereka sendiri (Hernowo, 2000).

Selain strategi pembelajaran TANDUR dikenal pula strategi pembelajaran ekspositori yang dilakukan guru untuk mengatakan atau menjelaskan fakta-fakta, gagasan-gagasan dan informasi penting lainnya kepada para peserta didik. Strategi pembelajaran ekspositori adalah strategi pembelajaran yang menekankan kepada proses penyampaian materi secara verbal dan dapat menguasai materi pelajaran secara optimal dengan tujuan materi pelajaran dapat disampaikan secara langsung, dan siswa tidak dituntut untuk menemukan materi tersebut (Sanjaya, 2010).

Kelebihan dari strategi pembelajaran TANDUR adalah merangsang siswa lebih aktif mengamati, menyesuaikan antara teori dan kenyataan dan dapat melakukannya sendiri, sedangkan strategi pembelajaran ekspositori merupakan strategi pembelajaran yang sangat efektif apabila materi pelajaran yang harus dikuasai siswa cukup luas, sementara itu waktu yang dimiliki sangat terbatas, selain itu juga guru mampu mengontrol urutan dan keluasan materi pelajaran sehingga mampu mengetahui sejauh mana siswa menguasai materi pelajaran yang disampaikan. Kedua strategi pembelajaran ini diharapkan mampu meningkatkan motivasi belajar dan hasil belajar siswa. Oleh karena itu dilaksanakan eksperimen untuk membandingkan strategi pembelajaran TANDUR dengan strategi pembelajaran ekspositori, kemudian memilih diantara kedua strategi tersebut yang paling tepat untuk belajar biologi.

Berdasarkan permasalahan diatas maka penulis mengangkat penelitian dengan judul "Perbadingan Motivasi Belajar dan Hasil Belajar Biologi Materi Sistem Indera Melalui Strategi Pembelajaran TANDUR dan Strategi Pembelajaran ekspositori pada Siswa Kelas XI IPA SMA 8 Makassar”.

\section{B. METODE}

Penelitian ini merupakan jenis penelitian eksperimen semu (Quasy Experiment) yang bertujuan membandingkan motivasi belajar dan hasil belajar materi sistem indera melalui strategi pembelajaran TANDUR dan strategi pembelajaran ekspositori pada siswa kelas XI IPA SMA Negeri 8 Makassar. Populasi dalam penelitian ini adalah siswa kelas XI IPA SMA Negeri 8 Makassar semester ganjil tahun ajaran 2017/2018. Sampel dalam penelitian ini adalah siswa kelas XI IPA4 dan XI IPA5 SMA Negeri 8 Makassar semester Ganjil tahun ajaran 2017/2018 yang berjumlah 71 orang, diperoleh dengan menggunakan Simple Random Sampling, kelas XI IPA5 diajar melalui strategi pembelajaran TANDUR dengan jumlah siswa sebanyak 38 orang, sedangkan kelas XI IPA4 diajar melalui strategi pembelajaran ekspositori 
dengan jumlah siswa sebanyak 33 orang. Instrumen yang digunakan dalam penelitian ini adalah angket motivasi dan tes hasil belajar. Teknik pengumpulan data pada penelitian ini adalah dengan mengevaluasi hasil belajar melalui tes tertulis, dan mngetahui tingkat motivasi belajar siswa melalui angket motivasi belajar.

\section{HASIL DAN PEMBAHASAN}

\section{Hasil Penelitian}

\section{a. Analisis Statistik Deskriptif}

\section{(1) Motivasi Belajar Siswa Melalui Strategi Tandur}

Analisis statistik deskriptif ini bertujuan untuk mendeskripsikan motivasi belajar yang diperoleh siswa setelah mengikuti materi sistem indera pada kelas yang diajar dengan strategi TANDUR. Hasil motivasi belajar biologi pada konsep sistem indera siswa kelas XI SMA Negeri 8 Makassar melalui strategi pmebelajaran TANDUR dapat dilihat pada lampiran 4. Distribusi motivasi belajar sistem kelas XI SMA
Negeri 8 Makassar pada konsep sistem indera melalui strategi pembelajaran TANDUR dapat dilihat pada Tabel 4.1.

\begin{tabular}{cc}
\hline Statistik Deskriptif & $\begin{array}{c}\text { Kelas yang Diajar } \\
\text { Melalui Strategi } \\
\text { Pembelajaran } \\
\text { TANDUR }\end{array}$ \\
\hline Jumlah Sampel (N) & 38 \\
\hline Nilai Tertinggi & 134 \\
\hline Nilai Terendah & 55 \\
\hline Rata-rata & 112.26 \\
\hline Standar Deviasi & 15.5 \\
\hline Median & 115 \\
\hline Modus & 113 \\
\hline
\end{tabular}

Seluruh nilai yang diperoleh siswa akan dikelaskan dalam pengkategorian motivasi belajar. Berikut adalah tabel skala lima yang merujuk pada Slameto (1999) yang menunjukkan frekuensi dan persentase kategori motivasi belajar siswa yang diajar melalui strategi pembelajaran TANDUR, dapat dilihat pada table 4.2.

Tabel 4.2 Distribusi Frekuensi Dan Persentase Kategori Motivasi Belajar Biologi Siswa Kelas XI IPA di SMA Negeri 8 Makassar Melalui Strategi Pembelajaran Tandur

\begin{tabular}{cccc}
\hline \multirow{2}{*}{ Interval Skor } & \multirow{2}{*}{ Kategori } & \multicolumn{2}{c}{ Kelas yang Diajar Melalui Strategi TANDUR } \\
\cline { 3 - 4 } & & Frekuensi & Persentase (\%) \\
\hline \hline $\mathbf{8 9}$ & Sangat Rendah & 3 & 7.89 \\
\hline $\mathbf{8 9}-\mathbf{1 0 4}$ & Rendah & 3 & 7.89 \\
\hline $\mathbf{1 0 5}-\mathbf{1 2 0}$ & Sedang & 22 & 57.89 \\
\hline $\mathbf{1 2 1}-\mathbf{1 3 5}$ & Tinggi & 10 & 26.33 \\
\hline$>\mathbf{1 3 5}$ & Sangat Tinggi & - & - \\
\hline & Jumlah & $\mathbf{3 8}$ & $\mathbf{1 0 0}$ \\
\hline
\end{tabular}

Berdasarkan Tabel 4.2 dapat diketahui bahwa interval skor $<89$ merupakan kategori sangat rendah dengan frekuensi $3(7.89 \%)$, interval skor 89-104 termasuk ke dalam kategori rendah dengan frekuensi sebesar 3 $(7.89 \%)$, interval skor $105-120$ termasuk kategori sedang dengan frekuensi 22 (57.89\%), interval skor 121-135 termasuk kategori tinggi dengan frekuensi 10 (26.33\%). Jika dilihat dari hasil tersebut, persentase total untuk kategori sedang dan tinggi adalah $84.22 \%$ sedangkan persentase total untuk kategori rendah dan sangat rendah $15.78 \%$.

\section{(2) Motivasi Belajar Siswa Melalui Strategi Pembelajaran Ekspositori}

Analisis statistik deskriptif ini bertujuan untuk mendeskripsikan motivasi belajar yang diperoleh siswa setelah mengikuti materi sistem indera pada kelas yang diajar dengan strategi pembelajaran ekspositori. Hasil motivasi belajar biologi pada konsep sistem indera siswa kelas XI SMA Negeri 8 Makassar melalui strategi pembelajaran ekspositori dapat dilihat pada lampiran 4. Distribusi motivasi belajar sistem kelas XI SMA Negeri 8 Makassar pada konsep sistem indera melalui 


\begin{tabular}{cc}
\hline Statistik Deskriptif & $\begin{array}{c}\text { Kelas yang Diajar } \\
\text { melalui Strategi } \\
\text { Pembelajaran } \\
\text { Ekspositori }\end{array}$ \\
\hline Jumlah Sampel (N) & 33 \\
\hline Nilai Tertinggi & 118 \\
\hline Nilai Terendah & 94 \\
\hline Rata-rata & 103.24 \\
\hline Standar Deviasi & 8.90 \\
\hline Median & 98 \\
\hline Modus & 96 \\
\hline $\begin{array}{l}\text { strategi pembelajaran ekspositori dapat dilihat } \\
\text { pada tabel 4.3 berikut: }\end{array}$
\end{tabular}

Seluruh nilai yang diperoleh siswa akan dikelaskan dalam pengkategorian motivasi belajar. Berikut adalah tabel skala lima yang merujuk pada Slameto (1999) yang menunjukkan frekuensi dan persentase kategori motivasi belajar siswa melalui strategi ekspositori yang ditunjukkan oleh Tabel 4.4

Tabel 4.4 Distribusi Frekuensi dan Persentase Kategori Motivasi Belajar Biologi Siswa Melalui Strategi Pembelajaran Ekspositori

\begin{tabular}{cccc}
\hline \multirow{2}{*}{ Interval Skor } & \multirow{2}{*}{ Kategori } & \multicolumn{2}{c}{$\begin{array}{c}\text { Kelas yang Diajar Melalui Strategi } \\
\text { Pembelajaran Ekspositori }\end{array}$} \\
\cline { 3 - 4 } & & Frekuensi & Persentase (\%) \\
\hline$<\mathbf{8 9}$ & Sangat Rendah & - & - \\
\hline $\mathbf{8 9 - 9 8}$ & Rendah & 17 & 51.52 \\
\hline $\mathbf{9 9}-\mathbf{1 0 7}$ & Sedang & 6 & 18.18 \\
\hline $\mathbf{1 0 8}-\mathbf{1 1 6}$ & Tinggi & 6 & 18.18 \\
\hline$>\mathbf{1 1 6}$ & Sangat Tinggi & 4 & 12.12 \\
\hline & Jumlah & $\mathbf{3 3}$ & $\mathbf{1 0 0}$ \\
\hline
\end{tabular}

Berdasarkan Tabel 4.4 dapat diketahui bahwa interval skor 89-98 termasuk ke dalam kategori rendah dengan frekuensi sebesar 17 (51.52\%), interval skor 99-107 termasuk kategori sedang dengan frekuensi 6 (18.18\%), interval skor 108-116 termasuk kategori tinggi dengan frekuensi $6(18.18 \%)$, dan interval

\begin{tabular}{cc}
\hline Statistik Deskriptif & $\begin{array}{c}\text { Kelas yang Diajar } \\
\text { Melalui Strategi } \\
\text { Pembelajaran } \\
\text { TANDUR }\end{array}$ \\
\hline Jumlah Sampel (N) & 38 \\
\hline Nilai Tertinggi & 96 \\
\hline Nilai Terendah & 72 \\
\hline Rata-rata & 83.68 \\
\hline Standar Deviasi & 5.83 \\
\hline Median & 84 \\
\hline Modus & 84 \\
\hline $\begin{array}{l}\text { skor >116 termasuk kategori sangat tinggi } \\
\text { dengan frekuensi 4 (12.12\%). Jika dilihat dari }\end{array}$ \\
hasil tersebut, persentase total untuk kategori
\end{tabular}

sedang, tinggi dan sangat tinggi adalah $48.48 \%$ sedangkan persentase total untuk kategori rendah dan sangat rendah 51.52\%.

\section{(3) Hasil Belajar Biologi Siswa Melalui Strategi Pembelajaran TANDUR}

Analisis statistik deskriptif ini bertujuan untuk mendeskripsikan hasil belajar yang diperoleh siswa setelah mengikuti materi sistem indera pada kelas yang diajar melalui strategi pembelajaran TANDUR. Hasil belajar biologi pada konsep sistem indera siswa kelas XI SMA Negeri 8 Makassar melalui strategi pembelajaran TANDUR dapat dilihat pada lampiran 4. Distribusi hasil belajar sistem kelas XI SMA Negeri 8 Makassar pada konsep sistem indera melalui strategi pembelajaran TANDUR dapat dilihat pada tabel 4.5.

$\begin{array}{cccc}\text { Pengkategorian hasil belajar biologi } & \text { bion } \\ \text { siswa yang diajar melalui } & \text { strategi }\end{array}$


pembelajaran TANDUR pada materi sistem indera dapat dilihat pada Tabel 4.6.

Tabel 4.6. Distribusi, Frekuensi, Persentase Dan Kategori Hasil Belajar Pada Materi Sistem Indera Siswa yang Diajar Melalui Strategi Pembelajaran TANDUR strategi pembelajaran ekspositori dapat dilihat pada tabel 4.7

\begin{tabular}{cccc}
\hline \multirow{2}{*}{ Interval Nilai } & \multicolumn{2}{c}{ Kelas Yang Diajar Melalui Strategi Pembelajaran } & \multirow{2}{*}{ Kategori } \\
\cline { 2 - 4 } & \multicolumn{3}{c}{ TANDUR } \\
\\
\cline { 2 - 4 } $\mathbf{8 5 - 1 0 0}$ & $\mathbf{F}$ & $\mathbf{P}(\%)$ & \\
\hline $\mathbf{7 0 - 8 4}$ & $\mathbf{3 1}$ & $\mathbf{1 8 , 4 2}$ & Amat baik \\
\hline $\mathbf{5 0 - 6 9}$ & $\mathbf{0}$ & $\mathbf{0}$ & Baik \\
\hline$<49$ & $\mathbf{0}$ & $\mathbf{0}$ & Cukup \\
\hline Jumlah & $\mathbf{3 8}$ & $\mathbf{1 0 0}$ & Kurang \\
\hline
\end{tabular}

Tabel 4.6 menunjukkan distribusi nilai yang diperoleh siswa, yang dikelompokkan menjadi empat kategori yang merujuk pada Depdikbud (2008), tentang pengkategorian tingkat penguasaan hasil belajar biologi. Tabel tersebut menunjukkan interval nilai $85-100$ dengan frekuensi $7 \quad(18,42 \%)$ termasuk kategori amat baik dan interval nilai 70-84 dengan frekuensi $31 \quad(81.58 \%)$ termasuk kategori Baik.

\section{(4) Hasil Belajar Biologi Siswa Melalui Strategi Pembelajaran Ekspositori}

Analisis statistik deskriptif ini bertujuan untuk mendeskripsikan hasil belajar yang diperoleh siswa setelah mengikuti materi sistem indera pada kelas yang diajar melalui strategi pembelajaran ekspositori. Hasil belajar biologi pada konsep sistem indera siswa kelas XI SMA Negeri 8 Makassar yang diajar melalui strategi pembelajaran ekspositori dapat dilihat pada lampiran 4. Distribusi hasil belajar sistem kelas XI SMA Negeri 8 Makassar pada konsep sistem indera yang diajar melalui
Tabel 4.7 Distribusi Hasil Belajar Biologi Siswa yang Diajar Melalui Strategi Pembelajaran Ekspositori

\begin{tabular}{cc}
\hline Statistik Deskriptif & $\begin{array}{c}\text { Kelas Yang Diajar } \\
\text { melalui Strategi } \\
\text { Pembelajaran } \\
\text { Ekspositori }\end{array}$ \\
\hline Jumlah Sampel (N) & 33 \\
\hline Nilai Tertinggi & 96 \\
\hline Nilai Terendah & 72 \\
\hline Rata-rata & 79.75 \\
\hline Standar Deviasi & 5.73 \\
\hline Median & 80 \\
\hline Modus & 76 \\
\hline
\end{tabular}

Pengkategorian hasil belajar biologi siswa yang diajar melalui strategi pembelajaran ekspositori pada materi sistem indera dapat dilihat pada Tabel 4.8

Tabel 4.8. Distribusi, frekuensi, persentase dan kategori hasil belajar pada materi sistem indera siswa melalui Strategi pembelajaran Ekspositori

\begin{tabular}{|c|c|c|c|}
\hline \multirow[t]{2}{*}{ Interval Nilai } & \multicolumn{2}{|c|}{$\begin{array}{c}\text { Kelas Yang Diajar Melalui Strategi } \\
\text { Ekspositori }\end{array}$} & \multirow[t]{2}{*}{ Kategori } \\
\hline & $\mathbf{F}$ & $\mathbf{P}(\%)$ & \\
\hline $85-100$ & 5 & 15.15 & Amat baik \\
\hline $70-84$ & 28 & 84.85 & Baik \\
\hline $50-69$ & $\mathbf{0}$ & $\mathbf{0}$ & Cukup \\
\hline$<49$ & 0 & 0 & Kurang \\
\hline Jumlah & 38 & 100 & \\
\hline
\end{tabular}


Tabel 4.8 menunjukkan distribusi nilai yang diperoleh siswa, yang dikelompokkan menjadi emapat kategori yang merujuk pada Depdikbud (2008), tentang pengkategorian tingkat penguasaan hasil belajar biologi. Tabel tersebut menunjukkan interval nilai $85-100$ dengan frekuensi $5(15,15 \%)$ termasuk kategori amat baik dan interval nilai $70-84$ dengan frekuensi 28 (84.85\%) termasuk kategori Baik.

\section{b. Analisis Statistik Inferensial \\ (1) Motivasi Belajar \\ a) Uji Normalitas}

Berdasarkan hasil pengelolaan data melalui program SPSS 18.0, nilai KolmogorovSmirnov untuk motivasi belajar yang diperoleh dari kelas yang diajar melalui strategi pembelajaran Tandur adalah $0,271>\alpha(0,05)$ dan nilai Kolmogorov-Smirnov yang diperoleh dari kelas yang diajar melalui strategi pembelajaran ekspositori adalah $0.056>\alpha$ $(0,05)$. Hasil tersebut menunjukkan bahwa data terdistribusi normal baik pada kelas yang diajar melalui strategi pembelajaran TANDUR maupun kelas yang diajar melalui strategi pembelajaran ekspositori.

\section{b) Uji Homogenitas}

Berdasarkan hasil perhitungan dan pengelolaan data yang dilakukan melalui program SPSS 18.0, diperoleh nilai signifikansi $0,161>\alpha$ $(0,05)$, dapat disimpulkan bahwa kedua kelompok data yaitu kelas yang diajar melalui strategi pembelajaran TANDUR dan kelas yang diajar melalui strategi pembelajaran ekspositori memiliki varian yang sama atau homogeny.

\section{c) Uji Hipotesis}

Setelah diketahui bahwa data yang diperoleh telah terdistribusi normal dan memiliki varian yang sama, maka dilakukan uji-t dengan meggunakan program SPSS versi 18.0 untuk menguji hipotesis penelitian. Nilai sig. (2tailed) yang diperoleh dari uji hipotesis ialah $0,024<\alpha(0,05)$. Berdasarkan kriteria tersebut maka H0 ditolak dan H1 diterima, sehingga dapat disimpulkan bahwa terdapat perbedaan motivasi belajar siswa kelas XI IPA SMA Negeri 8 Makassar yang diajar melalui strategi pembelajaran TANDUR dan strategi pembelajaran ekspositori.

\section{(2) Hasil Belajar}

a) Uji Normalitas

Berdasarkan hasil pengelolaan data melalui program SPSS 18.0, nilai KolmogorovSmirnov untuk hasil belajar yang diperoleh dari kelas yang diajar melalui strategi pembelajaran Tandur adalah $0,059>\alpha(0,05)$ dan nilai Kolmogorov-Smirnov yang diperoleh oleh kelas yang diajar melalui strategi pembelajaran ekspositori adalah $0.235>\alpha$ $(0,05)$. Hasil tersebut menunjukkan bahwa data terdistribusi normal baik pada kelas yang diajar melalui strategi pembelajaran TANDUR maupun kelas yang diajar melalui strategi pembelajaran ekspositori.

\section{b) Uji Homogenitas}

Berdasarkan hasil perhitungan dan pengelolaan data yang dilakukan melalui program SPSS 18.0, diperoleh nilai signifikansi $0,426>\alpha(0,05)$, dapat disimpulkan bahwa kedua kelompok data yaitu kelas yang diajar melalui strategi pembelajaran TANDUR dan kelas yang diajar melalui strategi pembelajaran ekspositori memiliki varian yang sama atau homogeny.

\section{c) Uji Hipotesis}

Setelah diketahui bahwa data yang diperoleh telah terdistribusi normal dan memiliki varian yang sama, maka dilakukan uji-t dengan meggunakan program SPSS versi 18.0 untuk menguji hipotesis penelitian. Nilai sig. (2-tailed) yang diperoleh dari uji hipotesis ialah $0,006<\alpha(0,05)$. Berdasarkan kriteria tersebut maka H0 ditolak dan $\mathrm{H} 1$ diterima, sehingga dapat disimpulkan bahwa terdapat perbedaan hasil belajar siswa kelas XI IPA SMA Negeri 8 Makassar yang diajar melalui strategi pembelajaran TANDUR dan strategi pembelajaran ekspositori.

\section{Pembahasan}

a. Motivasi Belajar

Berdasarkan hasil analisis data yang diperoleh, baik analisis statistik deskriptif maupun analisis statistik inferensial menunjukkan perbedaan motivasi belajar biologi materi sistem indera pada kelas yang 
diajar melalui strategi pembelajaran TANDUR maupun kelas yang diajar melalui strategi pembelajaran ekspositori. Perbedaan motivasi belajar kedua kelas dapat dilihat dari analisis deksriptif yaitu nilai rata-rata yang diperoleh siswa yang diajar melalui strategi TANDUR lebih tinggi (112.26) dibanding siswa yang diajar melalui strategi ekspositori (103.24). Berdasarkan pengkategorian skla lima yang merujuk pada Slamte (1999), yang menunjukkan frekuensi dan persentase kategori motivasi siswa yang diajar melalui strategi TANDUR dan strategi pembelajaran ekspositori. Untuk strategi pembelajaran TANDUR, persentase total untuk kategori sedang dan tinggi adalah $84.22 \%$ dan persentase total untuk kategori rendah dan sangat rendah adalah $15.78 \%$. Sedangkan untuk strategi pembelajaran ekspositori, persentase tatal untuk kategori sedang, tinggi, dan sangat tinggi adalah $48.48 \%$ dan persentase total untuk kategori rendah dan sangat rendah adalah $51.52 \%$.

Melalui teknik analisis statistik inverensial dengan menggunakan program SPSS 18.0 dipeoleh nilai sig (2-tailed) $0.024<$ $\alpha$ 0.05. Berdasarkan kriteria tersebut maka $\mathrm{HO}$ ditolak dan H1 diterima, sehingga dapat disimpulkan bahwa terdapat perbedaan hasil belajar materi sistem indera siswa kelas XI IPA SMA 8 Makassar melalui strategi pembelajaran TANDUR dan strategi pembelajaran ekspositori.

Berdasarkan analisis deskriptif maupun analisis inferensial, terlihat bahwa siswa yang diajar melalui strategi pembelajaran TANDUR tingkat motivasinya lebih tinggi dibanding dengan kelas yang diajar melalui melalui strategi pembelajaran ekspositori. Hal ini diduga karena motivasi belajar siswa pada kelas yang diajar melalui strategi pembelajaran TANDUR dimunculkan pada awal pembelajaran maupun pada saat proses pembelajaran berlangsung. Motivasi belajar yang dimunculkan berupa pemberian kasus yang berhubungan dengan sistem indera untuk menarik perhatian dan menumbuhkan rasa ingin tahu siswa. Lain halnya dengan kelas yang diajar melalui strategi pembelajaran ekspositori yang tanpa memberikan motivasi yang serupa.

Adanya perhatian dan rasa ingin tahu yang tinggi, maka muncul suatu kebutuhan siswa untuk memuaskan rasa ingin tahunya. Hal tersebut sesuai dengan pernyataan Sanjaya (2010:29) bahwa kebutuhan akan mendorong timbulnya motivasi. Begitu juga dengan penyampaian tujuan pembelajaran pada awal pembelajaran, sesuai dengan pendapat Hamalik (2007) bahwa seseorang yang telah mengetahui tujuan yang hendak dicapai,maka perbuatan kearah tersebut akan semakin besar daya dorongnya. Selain itu, strategi pembelajaran TANDUR juga memiliki beberpa keunggulan yang terdapat dalam setiap fasenya. Adapun fase dari strategi pembelsjaran TANDUR dapat dilihat pada table berikut:

\begin{tabular}{lll}
\hline \hline No & \multicolumn{1}{c}{ Fase } & \multicolumn{1}{c}{ Strategi } \\
\hline \hline 1. & Tumbuhkan & $\begin{array}{l}\text { Menjelaskan tujuan pembelajaran mengenai materi sistem indera } \\
\text { serta mengetahui manfaat yang diperoleh setelah mempelajari } \\
\text { materi sistem indera melalui AMBAK }\end{array}$ \\
\hline 2. & Alami & $\begin{array}{l}\text { Menggunakan metode yang bervariasi, membantu kesulitan anak } \\
\text { didik secara individual maupun kelomok dan menggunakan media } \\
\text { yang baik dan sesuai dengan tujuan pembelajaran }\end{array}$ \\
\hline \hline 3. & Namai & \\
\hline 4. & Demonstrasikan & $\begin{array}{l}\text { Mengadakan persaingan diantara siswanya untuk meningkatkan } \\
\text { prestasi belajarnya, berusaha memperbaiki hasil prestasi yang telah } \\
\text { dicapai sebelumnya }\end{array}$ \\
\hline 5. & Ulangi & $\begin{array}{l}\text { Memberikan penghargaan atau pujian kepada siswa dan } \\
\text { memberikan hadiah untuk siswa yang berhasil }\end{array}$ \\
\hline 6. & Rayakan &
\end{tabular}


Adanya AMBAK (Apakah Manfaatnya BagiKu) yang dapat mendorong siswa untuk memunculkan keinginan mempelajari materi sistem indera. DePorter et al. (2002) mengungkapkan bahwa siswa akan termotivasi melakukan seuatu bila kegiatan tersebut bermanfaat baginya. Penggunaan strategi yang inovatif tercantum pada fase alami, namai, dan demonstrasikan. Strategi yang inovatif membuat siswa tidak merasa jenuh untuk belajar. Seperti yang diungkapkan oleh Deporter et al. (2002) bahwa penggunaan berbagai strategi dalam pembelajaran membuat siswa lebih betah lama-lama untuk melakukan kegiatan belajar. Oleh sebab itu motivasi dapat dipertahankan sampai akhir pembelajaran.

Strategi pembelajaran TANDUR memberikan kegiatan yang lebih bervariasi. Dengan adanya kegiatan yang bervariasi menghindari tingkat kejenuhan siswa sehigga siswa terus termotivasi untuk melakukan proses belajar. Sedangkan pembelajaran pada kelas yang diajar melalui startegi pembelajaran ekspositori pemberian apersepsi diawal pembelajaran yang bertujuan unutk meningkatkan motivasi siswa hanya sebatas pengenalan materi kepada siswa. Selain itu pada strategi pembelajaran ekspositori siswa hanya sebatas mengisi LKS, dan tanya jawab sehingga rawan untuk terjadinya kebosanan. Kondisi siswa yang bosan akan berdampak pada motivasi belajarnya.

Walaupun motivasi belajar dan hasil belajar siswa dibahas terpisah, namun keduanya memiliki hubungan yang tidak dapat dipisahkan. Motivasi dan penguasan konsep dalam hal ini adalah hasil belajar siswa memiliki pengaruh satu sama lain karena menurut Sudjana (2006) motivasi mempengaruhi taraf penguasaan konsep siswa yang termasuk ke dalam hasil belajar.

\section{b. Hasil Belajar}

Berdasarkan hasil analisis data yang diperoleh, baik analisis statistik deskriptif maupun analisis statistik inferensial menunjukkan perbedaan hasil belajar biologi materi sistem indera pada kelas yang diajar melalui strategi pembelajaran TANDUR maupun kelas yang diajar melalui strategi pembelajaran ekspositori. Perbedaan hasil belajar kedua kelas dapat dilihat dari analisis deksriptif yaitu nilai rata-rata yang diperoleh siswa yang diajar melalui strategi TANDUR lebih tinggi (83.68) dibanding siswa yang diajar melalui strategi ekspositori (79.75). Berdasarkan pengkategorian tingkat penguasaan hasil belajar biologi yang merujuk pada Depdikbud (2008), dimana pesentase siswa yang memiliki interval nilai $85-100$ (kategori amat baik) yaitu $18.42 \%$ dan kategori persentase siswa yang memiliki interval nilai 70-84 (kategori baik) yaitu $81.58 \%$. Sedangkan pada strategi pembelajaran ekspositori , persentase siswa yang memiliki interval nilai 85-100 (kategori amat baik) yaitu $15.15 \%$ dan persentase siswa yang memiliki interval nilai 70-84 (kategori baik) sebesar $84.85 \%$.

Hasil analisis data secara inferensial juga memperlihatkan adanya perbedaan hasil belajar biologi siswa yang diaajar melalui strtaegi pembelajaran TANDUR dan startegi pembelajaran ekspositori. Melalui teknik analisis statistik inverensial dengan menggunakan program SPSS 18.0 dipeoleh nilai sig (2-tailed) $0.006<\alpha 0.05$. Berdasarkan kriteria tersebut maka $\mathrm{H} 0$ ditolak dan $\mathrm{H} 1$ diterima, sehingga dapat disimpulkan bahwa terdapat perbedaan hasil belajar materi sistem indera siswa kelas XI IPA SMA 8 Makassar melalui strategi pembelajaran TANDUR dan strategi pembelajaran ekspositori.

Adanya perbedaan hasil belajar biologi siswa diduga dipengaruhi oleh kegiatan pembelajaran yang dilaksanakan. Walaupun media yang digunakan pada kedua kelas tersebut sama, namun pembelajaran pada kelas yang diajar melalui strategi pembelajaran TANDUR melibatkan proses pengalaman (fase alami), penamaan (fase namai), aplikasi (fase demonstrasikan), serta pengulangan (fase ulangi). Adanya fase-fase tersebut siswa tidak hanya dibantu untuk menguasai konsep, tapi juga diarahkan untuk dapat menggunakan pengetahuan yang telah mereka miliki kedalam situasi yang baru terutama yang berkaitan dengan kehidupan sehari-hari. Fase-fase yang terdapat pada strategi TANDUR membuat materi pembelajaran menjadi nyata bagi siswa untu mencapai sukses dalam belajar (Deporter et al., 2002).

Hasil belajar dikelas yang diajar melalui strategi pembelajarn TANDUR lebih 
tinggi karena adanya pengalaman (fase alami) yang memberikan kesempatan kepada siswa menggali rasa ingin tahu mereka. Dengan demikian kegiatan yang melibatkan pengalaman membuat pembelajaran menjadi lebih bermanka sehingga siswa lebih banyak mengingat materi yang mereka pelajari.

Kelas yang diajar melalui strategi TANDUR dan kelas yang diajar mealalui strategi ekspositori memperoleh pengalaman belajar melalui pemberian LKS. Melalui keagiatan tersebut siswa pada kedua kelas diharapkan mampu memaknai konsep-konsep melalui penyelesaina soal-soal. Akan tetapi pada kelas yang diajar melalui strategi TANDUR pemberian LKS didahului dengan pengalaman belajar berupa demonstrasi yang tidak dilakukan oleh kelas yang diajar melalui strategi ekspositori. Siswa dapat dikatakan memahami suatu konsep ketika mereka dapat membangun makna dari pesan pembelajaran, termasuk komunikasi lisan dan tulisan (Anderson et al., 2001). Selain itu peningkatan hasil belajar pada siswa kelas yang diajar melalui strategi pembelajaran TANDUR ditunjang oleh proses pengulangan (fase ulangi) berupa reinforcement "Aku Tahu Bahwa Aku Tahu" yang akan memperkuat penguasaan konsep siswa. Berbeda dengan kelas yang diajar melalui strategi ekspositori diberikan jenis pengulangan dengan tanya jawab seperti biasa. Fase ulangi yang disertai reinforcement membuat koneksi saraf menyimpan iformasi menjadi lebih kuat (DePorter et al., 2002).

Materi sistem indera merupakan pengetahuan faktual yang menyajikan sejumlah informasi atau fakta tentang sistem indera pada manusia yang berkaitan erat dengan kehidupan sehari-hari. Konsep ini baik diajarkan melalui strategi pembelajaran TANDUR maupun strategi pembelajaran ekspositori. Berdasarkan nilai rata-rata dan ketuntasan dari hasil belajar siswa yang diperoleh, tidak dapat dipungkiri bahwa terdapat faktor eksternal yang tidak dapat dikontrol yang ikut mempengaruhi. Hal ini sejalan dengan apa yang dikemukakan oleh Hadi (1986: 437) bahwa dalam tiap-tiap eksperimen, hasil yang berbeda antara kelompok pembanding dan kelompok yang dibanding sebagian disebabkan oleh variabel eksperimental yang meliputi kondisi yang hendak diselidiki yaitu penerapan strategi pembelajaran TANDUR dan strategi pembejaran ekspositori, dan sebagian lagi karena variabel ektrane, yaitu variabel non eksperimental yang berada diluar kekuasaan eksperimen untuk dikontrol atau dikendalikan.

Peneliti menyadari bahwa tidak mudah untuk meningkatkanmotivasi dan hasil belajar siswa, apalagi dengan kemampuan siswa yang masih terbatas khususnya pemahaman biologi. Jadi yang terpenting adalah bagaimana pengelolaan kelas, menumbuhkan minat dan antusias siswa, memiliki keberanian baik mengajukan, menanggapi, maupun menjawab pertanyaan, pemilihan model dan strategi pembelajaran. Walaupun tidak mudah untuk melakukan hal tersebut, namun dengan menerapkan strategi pembelajaran TANDUR terbukti dapat meningkatkan motivasi dan hasil belajar siswa.

\section{KESIMPULAN DAN SARAN \\ 1. Kesimpulan}

Berdasarkan hasil penelitian, analisis data, dan pembahasan, maka dapat disimpulkan bahwa; (1) Motivasi belajar kelas yang diajar melalui strategi TANDUR untuk kategori sangat rendah $7.89 \%$, rendah $7.89 \%$, sedang $57.89 \%$, tinggi $26.33 \%$, sedangkan motivasi belajar kelas yang diajar melalui strategi ekspositori untuk kategori rendah $51.53 \%$, sedang $18.18 \%$, tingg $18.18 \%$, sangat tinggi $12.12 \%$; (2) Hasil belajar biologi materi sistem indera yang diajar melalui strategi TANDUR untuk kategori amat baik $18.42 \%$, baik $81.58 \%$, sedangkan hasil belajar kelas yang diajar melalui startegi ekspositori unutk kategori amat baik $15.15 \%$, baik $84.85 \%$; (3) Ada perbedaan motivasi belajar melalui strategi pembelajaran TANDUR dan strategi pembelajaran ekspositori siswa kelas XI IPA SMA Negeri 8 Makassar, dimana motivasi belajar siswa melalui strategi TANDUR lebih tinggi dibanding dengan strategi ekspositori; (4) Ada perbedaan hasil belajar biologi materi sistem indera melalui strategi pembelajaran TANDUR dan strategi pembelajaran ekspositori siswa kelas XI IPA SMA Negeri 8 Makassar, dimana hasil belajar dengan menerapkan strategi TANDUR lebih tinggi 
dibanding dengan penerapan strategi ekspositori.

\section{Saran}

Sehubungan dengan kesimpulan hasil penelitian di atas, maka saran yang dapat dikemukakan oleh peneliti adalah; (1) Strategi pembelajaran TANDUR dapat menjadi salah satu alternatif pembelajaran yang dapat diterapkan untuk meningkatkan motivasi dan hasil belajar biologi siswa; (2) Diharapkan kepada guru bidang studi untuk menerapkan model serta strategi pembelajaran yang tepat dalam mengajar disetiap pokok bahasan agar tujuan pembelajaran dapat tercapai; (3) Diharapkan pada peneliti selanjutnya agar mengembangkan dan memperkuat hasil penelitian ini dengan mengadakan pengkajian lebih lanjut serta memperbaiki segala kekurangan penelitian ini demi kesempurnaannya.

\section{E. DAFTAR PUSTAKA}

Arikunto, Suharsimi. 2009. Dasar-Dasar Evaluasi Pendidikan. Jakarta: Bumi Aksara.

Arikunto, Suhardjono, dan Supardi. 2007. Penelitian Tindakan Kelas. Bumi Aksara: Jakarta.

Deporter, B. Reardon, M. dan Nourine, S.S (2002). Quantum Teaching, Mempraktikkan Quantum Learning di Ruang-ruang kelas. Bandung: Kaifa

Deporter, Bobbi dan Mike Hernacki. 2002. Quantum Learning: Membiasakan Belajar Nyaman Dan Menyenangkan. Kaifa: Bandung

Depdiknas. 2003. Undang-Undang RI No. 20 Tahun 2003 Tentang Sistem Pendidikan Nasional. Jakarta : Biro Hukum dan Organisasi

Djamarah, Syaiful Bahri dan Aswan Zain. 2006. Strategi Belajar Mengajar. Rineka Cipta: Jakarta.
Hamalik, Oemar. 2004. Proses Belajar Mengajar. Jakarta: PT. Bumi Aksara

Hernowo. 2000. Quantum Teaching. Bandung: Kaifa.

Makmun, S.S. 2005. Psikologi Kependidikan. Bandung: PT. Remaja Rosdakarya

Nurhayati. 2011. Strategi Belajar Mengajar. Universitas Negeri Makassar. Makassar.

Sabri, Ahmad. 2010. Strategi Belajar Mengajar dan Micro Teaching. PT Ciputat Press: Padang.

Sahabuddin. 2007. Mengajar dan Belajar. Universitas Negeri Makassar. Makassar.

Sanjaya. Wina. 2009. Strategi Pembelajaran Berorientasi Standar Proses Pendidikan. Jakarta: Kencana Prenada Media Group

Syaefudin, Udin. 2008. Inovasi Pendidikan. Bandung: Alfabeta.

Sudjana, 2006. Metode Statistika. Bandung: Tarsito.

Sudjana, Nana. 2002. Penelitian dan Penelitian Pendidikan. Bandung : Sinar Baru Algesindo.

Sugiyono. 2010. Metode Penelitian Pendidikan. Bandung: Alfabeta.

Tella A. 2007. The Impact of Motivation on Student Academic Accicment and Learning Outcomes in Mathematics Among Secondari School Students in Nigeria. Eurasia Journal of Mathematics, Science, and Technology Education, 3(2), 149-156.

Tekkaya, C., Ozkan, O. dan Sungur, S. (2001). "Biology Concepts Percieved as Difficult by Turkish High School Students". Journal of Education. 21, 145-150

Trianto. 2007. Model-model Pembelajaran Inovatif Berorientasi Konstruktivistik.. Jakart: Presentsi Pustaka

Uno, Hamzah. 2007. Teori Motivasi dan Pengukurannya Analisa di Bidang Pendidikan. Jakarta: PT. Bumi Aksara.

Webe, Agung. 2010. Smart Teaching. Yogyakarta: Jogja Bangkit Publisher. 